\title{
One Step In-Situ Synthesis of Zinc Oxide Nanoparticles for Multifunctional Cotton Fabrics
}

\author{
Asif Javed ${ }^{1, *}$, Jakub Wiener ${ }^{1}$, Asta Tamulevičienè ${ }^{2,3} \mathbb{D}$, Tomas Tamulevičius ${ }^{2,3} \mathbb{D}$, Algirdas Lazauskas ${ }^{2} \mathbb{D}$, \\ Jana Saskova ${ }^{1}$ and Simas Račkauskas ${ }^{2,3}$ iD \\ 1 Department of Material Engineering, Faculty of Textile Engineering, Technical University of Liberec, \\ 46001 Liberec, Czech Republic; jakub.wiener@tul.cz (J.W.); jana.saskova@tul.cz (J.S.) \\ 2 Institute of Materials Science, Kaunas University of Technology, K. Baršausko St. 59, \\ LT-51423 Kaunas, Lithuania; asta.tamuleviciene@ktu.lt (A.T.); tomas.tamulevicius@ktu.lt (T.T.); \\ algirdas.lazauskas@ktu.lt (A.L.); simas.rackauskas@ktu.lt (S.R.) \\ 3 Department of Physics, Kaunas University of Technology, Studentu St. 50, LT-51423 Kaunas, Lithuania \\ * Correspondence: asif.javed@tul.cz
}

check for

updates

Citation: Javed, A.; Wiener, J.; Tamulevičienè, A.; Tamulevičius, T.; Lazauskas, A.; Saskova, J.;

Račkauskas, S. One Step In-Situ Synthesis of Zinc Oxide Nanoparticles for Multifunctional Cotton Fabrics. Materials 2021, 14 3956. https://doi.org/10.3390/ ma14143956

Academic Editor: Benjamín Solsona

Received: 11 May 2021

Accepted: 11 July 2021

Published: 15 July 2021

Publisher's Note: MDPI stays neutral with regard to jurisdictional claims in published maps and institutional affiliations.

Copyright: (c) 2021 by the authors. Licensee MDPI, Basel, Switzerland. This article is an open access article distributed under the terms and conditions of the Creative Commons Attribution (CC BY) license (https:// creativecommons.org/licenses/by/ $4.0 /)$.

\begin{abstract}
Zinc oxide nanoparticles (ZnO NPs) have acquired great significance in the textile sector due to their impressive efficiency and multifold utilization, such as antimicrobials, UV protection, photo catalytic activity, and self-cleaning. The aim of this work is in-situ growth of ZnO NPs on $100 \%$ cotton fabrics with the one-step hydrothermal method for preparation of multifunctional textile with UV protecting, antibacterial, and photo catalytic properties. Sodium hydroxide $(\mathrm{NaOH})$ and Zinc nitrate hexahydrate $\left[\mathrm{Zn}\left(\mathrm{NO}_{3}\right)_{2} \cdot 6 \mathrm{H}_{2} \mathrm{O}\right]$ were used as reactants for the growth of zinc oxide on the $100 \%$ cotton fabrics. The loaded amount of $\mathrm{Zn}$ contents on the cotton fabric was determined by using induced coupled plasma atomic emission spectroscopy (ICP-AES). The surface morphological characterization of deposited ZnO NPs was examined, employing scanning electron microscopy (SEM), X-ray powder diffraction (XRD) and, Fourier- transform infrared spectroscopy (FTIR). The characterization results showed the presence of $\mathrm{ZnO}$ NPs on cotton fabrics having hexagonal wurtzite crystalline structure. The synthesized ZnO NPs on fabrics exhibited promising results for antibacterial, UV protection, and photo catalytic performance.
\end{abstract}

Keywords: ZnO; nanomaterials; metal oxide; antibacterial; UV protection; self-cleaning

\section{Introduction}

Metal oxides have increased the interest in multiple applications for manufacturing due to their remarkable properties. The crystalline structure metal oxides are even more effective at nano scale due to their advanced mechanical, physical, and chemical properties. These specific properties of metal oxides in connection to the enhancement of surface area at the nanometer scale(less than $100 \mathrm{~nm}$ ) [1-4]. In textile fabrication, metal oxides can be used to protect fabrics from UV, microbes, retard flame, conduct electricity, repel water, self-clean, etc. [5-8]. Zinc oxide $(\mathrm{ZnO})$, titanium dioxide $\left(\mathrm{TiO}_{2}\right)$, copper oxide $(\mathrm{CuO})$, and magnesium oxide $(\mathrm{MgO})$ are commonly used metal oxides in the textile industry as antibacterial agents [9-12]. For the UV protection and self-cleaning functionalities, nano-sized, and crystalline structure zinc oxide and titanium dioxide $\left(\mathrm{TiO}_{2}\right)$ are mostly used $[13,14]$. These inorganic metal oxides in the form of nanostructure are more effective and stable than organic materials used for the same application [15]. The nanostructures of metallic oxides release ions, and these ions cause the inactivation of the bacteria protein through reaction with a thiol group (-SH) in protein, which eventually kill bacteria [16]. The metal oxide nanoparticles can scatter, absorb, and block the UV radiation; they stop the UV radiation and shield the skin from dire effects $[15,17]$.

Zinc oxide is an inorganic metal oxide in the form of white powder. It is a versatile, non-toxic, and easy to synthesize multipurpose material having low-cost production, outstanding thermal, chemical, and mechanical stability [18]. ZnO is an n-type semiconductor 
material with a direct and wide band gap ( $3.37 \mathrm{eV})$, high excite on binding energy $(60 \mathrm{meV})$, and high electron mobility [16,19-21]. The extraordinary photo catalytic properties due to the electronic structure of $\mathrm{ZnO}$ nanoparticles also empower them to be used as degradation reagents for various types of pollutants; e.g., it can be used in the textile industry for dyes and surfactants degradation in the waste water. $\mathrm{ZnO}$ is made of $\mathrm{Zn}^{2+}$ and $\mathrm{O}^{2+}$ ions that are bonded with each other with a considerable extent of ionicity and with a minor degree of covalency [16,22-27].

$\mathrm{Up}$ to date, a number of articles address the research on the production of $\mathrm{ZnO}$ nanoparticles [16].

There are mainly two approaches for production: the top-down approach (metallurgical process); which involves the heating of the precious mineral zincite [23], and the bottom-up approach; which incorporates chemical, mechanical, and physical processes. Other methods, such as the sol-gel process, sonochemical, solvochemical, microwave irradiation method, hydrothermal system, precipitation techniques, and microemulsion are also used [28-32].

The multiple parameters and different conditions involved during the synthesis process, for example, synthesis method, reagents used, $\mathrm{pH}$ of the medium, the temperature of the process, the processing time, concentrations of the precursors, reaction medium of the process, drying temperature, and time, all of these influence the amount produced, structure and size of $\mathrm{ZnO}$ nanoparticles, as well as their performance and functional properties $[18,23,28,33]$. The crystalline $\mathrm{ZnO}$ nanoparticles have mainly been found in three crystal structures, i.e., wurtzite hexagonal structure, cubic zinc blende, and cubic rocksalt structure. However hexagonal wurtzite structure is thermodynamically stable under typical conditions; therefore this structure is commonly available [34].

$\mathrm{ZnO}$ nanoparticles are deposited onto textile materials mainly by the ex-situ route. However, pre-synthesized $\mathrm{ZnO}$ nanoparticles show minor adsorption onto the textile materials. Moreover, the ex-situ route leads to a pile-up of nanoparticles on the surface of textile fiber, which results in the reduction of functional properties of textile materials [35-37]. In-situ growth of $\mathrm{ZnO}$ onto the fabric is an alternative to ex-situ deposition. It has been observed that in-situ deposition results in a homogeneous distribution of nanoparticles, moreover they demonstrate excellent adsorption and adhesiveness, thus imparting long-lasting functional properties [23].

One of the most common and advantageous processes for $\mathrm{ZnO}$ nanoparticle synthesis is a hydrothermal process. This process has attracted immense interest as one of the most favorable techniques for controlling particle size. Hong et al. reported on hydrothermal application for seedless growth of $\mathrm{ZnO}$ on different fabrics using $\left[\mathrm{Zn}\left(\mathrm{NO}_{3}\right)_{2} \cdot 6 \mathrm{H}_{2} \mathrm{O}\right]$ as precursor (with nano rod structure) [38]. In another study, Baurah et al. adopted a hydrothermal process at $90{ }^{\circ} \mathrm{C}$ using $\left[\mathrm{Zn}\left(\mathrm{NO}_{3}\right)_{2} \cdot 6 \mathrm{H}_{2} \mathrm{O}\right]$ as precursor to develop cotton fabric based composite material containing $\mathrm{ZnO}$ nano rods (with average particle size 81 $\mathrm{nm}$ ) [39]. The hydrothermal method for $\mathrm{ZnO}$ has several advantages; moderate conditions are involved in the reaction, leading to nano-sized $\mathrm{ZnO}$ particles; with crystalline hexagonal wurtzite structure [40,41].

Shaheen et al. [42], El-Naggar et al. [43], and Zhang et al. [44] reported in-situ deposition of $\mathrm{ZnO}$ nanoparticles on textile fabrics; however, their approach in principle used a seeding method, where the textile fabric is immersed in a bath at a temperature range of 80 to $130{ }^{\circ} \mathrm{C}$ for the nuclei formation and further growth of nanoparticles on the fabric. The major disadvantage of the seeding method is its incompatibility on an industrial scale because of its time consuming approach [18,42-44].Therefore, there is a great need for an efficient method that is appropriate for the industrial scale of $\mathrm{ZnO} N P s$ on textile synthesis.

In this research work, the synthesis of $\mathrm{ZnO}$ nanoparticles on $100 \%$ cotton fabrics by one step in-situ hydrothermal method was investigated; UV protection, photocatalysis, and antibacterial properties were evaluated. Citric acid treatment for the surface activation leads to better adsorption and adhesion of $\mathrm{ZnO}$ nanoparticles to the $100 \%$ cotton fabrics. 
The optimal conditions to obtain the ZnO NP-based multifunctional textile including precursor ratios vs. the deposited amount of $\mathrm{ZnO}$ NPs on cotton are discussed.

\section{Materials and Methods}

\subsection{Materials}

The $100 \%$ cotton fabric with plain weave structure, $150 \mathrm{~g} / \mathrm{m}^{2}$ aerial density, 27 ends/inch, 23 picks/inch were purchased from the Lincolor industry Czech Republic. Citric acid $\mathrm{C}_{6} \mathrm{H}_{8} \mathrm{O}_{7}(\mathrm{CA})$, methyl orange $(\mathrm{MO})$, zinc nitrate hexahydrate $\left[\mathrm{Zn}\left(\mathrm{NO}_{3}\right)_{2} \cdot 6 \mathrm{H}_{2} \mathrm{O}\right]$, and sodium hydroxide $(\mathrm{NaOH})$ precursors were purchased from Sigma- Aldrich, Prague, Czech Republic. All the chemicals were of analytical standard and used as obtained without any further purification.

\subsection{Surface Activation of Cotton}

For maximum adhesion of $\mathrm{ZnO}$ NPs onto the cellulose structure of cotton fabric, the cotton fabric was pretreated with a $0.5 \%$ aqueous solution of citric acid for surface activation. As the citric acid and cotton fibers are added in deionized water, both are ionized as shown in Equations (1) and (2). In further reactions, carboxylic groups of citric acid were easily attached to the hydroxyl groups on cotton fabric, as shown in Equation (3) [45].

$$
\begin{gathered}
\mathrm{C}_{6} \mathrm{H}_{8} \mathrm{O}_{7}+\mathrm{H}_{2} \mathrm{O} \leftrightarrow \mathrm{C}_{6} \mathrm{H}_{7} \mathrm{O}_{7}^{-}+\mathrm{H}_{3} \mathrm{O}^{+}, \\
\text {Cellulose }-\mathrm{OH}+\mathrm{H}_{2} \mathrm{O} \leftrightarrow \text { Cellulose }-\mathrm{O}+\mathrm{H}_{3} \mathrm{O}^{+}, \\
\mathrm{C}_{6} \mathrm{H}_{7} \mathrm{O}_{7}^{-}+\text {Cellulose }-\mathrm{OH}+\mathrm{H}_{2} \mathrm{O} \leftrightarrow \text { Cellulose }-\mathrm{CA}+\mathrm{H}_{3} \mathrm{O}^{+} .
\end{gathered}
$$

\subsection{In-Situ Synthesis of Zinc Oxide on Cotton}

$\mathrm{ZnO}$ nanoparticles were deposited on cotton fabric by the hydrothermal method. $0.1 \mathrm{M}, 0.25 \mathrm{M}, 0.5 \mathrm{M}$ solutions of $\mathrm{Zn}\left(\mathrm{NO}_{3}\right)_{2} \cdot 6 \mathrm{H}_{2} \mathrm{O}$, and $\mathrm{NaOH}$ were prepared in deionized water. Then, $100 \mathrm{~mL}$ solution of $\mathrm{NaOH}$ was added drop-wise, vigorously stirred with $100 \mathrm{~mL}$ solution of $\mathrm{Zn}\left(\mathrm{NO}_{3}\right)_{2} \cdot 6 \mathrm{H}_{2} \mathrm{O}$. After $5 \mathrm{~min}$ of stirring $50 \mathrm{~mL}$ of the resulted solution was transferred into the autoclave. Then, the cotton fabric piece $(5 \mathrm{~cm} \times 5 \mathrm{~cm})$ was put into the autoclave. Afterwards the autoclave was put into the furnace and heated at $90{ }^{\circ} \mathrm{C}$ for $1 \mathrm{~h}$. After $1 \mathrm{~h}$ the autoclave was cooled at room temperature and the cotton fabric piece was taken out from the autoclave and dried in the oven at $90^{\circ} \mathrm{C}$ for $2 \mathrm{~h}$. The experimental design with different concentrations of $\mathrm{Zn}\left(\mathrm{NO}_{3}\right)_{2} \cdot 6 \mathrm{H}_{2} \mathrm{O}$ and $\mathrm{NaOH}$, as well as resulting responses of deposited amount of $\mathrm{Zn}$ contents onto fabric are shown in Table 1. Equations (4)-(7) describe the mechanism of $\mathrm{ZnO}$ nanoparticle synthesis on cotton fabric. A schematic diagram of $\mathrm{ZnO}$ nanoparticles loaded onto the cotton fabric is shown in Figure 1.

$$
\begin{aligned}
& \mathrm{Zn}\left(\mathrm{NO}_{3}\right)_{2} \cdot 6 \mathrm{H}_{2} \mathrm{O} \stackrel{\mathrm{H}_{2} \mathrm{O}}{\rightarrow} \mathrm{Zn}^{2+}+2 \mathrm{NO}_{3}^{-}+6 \mathrm{H}_{2} \mathrm{O}, \\
& \mathrm{NaOH} \stackrel{\mathrm{H}_{2} \mathrm{O}}{\rightarrow} \mathrm{Na}^{+}+\mathrm{OH}^{-}, \\
& \mathrm{Zn}^{2+}+4 \mathrm{OH}^{-} \rightarrow \mathrm{Zn}(\mathrm{OH})_{4}^{2-}, \\
& \mathrm{Zn}(\mathrm{OH})_{4}^{2-} \rightarrow \mathrm{ZnO}+\mathrm{H}_{2} \mathrm{O}+2 \mathrm{OH}^{-} \text {. }
\end{aligned}
$$


Table 1. Molar concentrations of the reagents and resulting $\mathrm{Zn}$ contents.

\begin{tabular}{|c|c|c|c|c|}
\hline Sample No. & $\begin{array}{l}\mathrm{Zn}\left(\mathrm{NO}_{3}\right)_{2} \cdot 6 \mathrm{H}_{2} \mathrm{O} \\
(\mathrm{M})\end{array}$ & $\begin{array}{l}\mathrm{NaOH} \\
(\mathrm{M})\end{array}$ & $\begin{array}{l}\text { Deposited Amount of Zn Contents onto Fabric } \\
\text { (gram/kg) }\end{array}$ & Standard Deviation \\
\hline Untreated & - & - & - & \\
\hline 1 & 0.1 & 0.1 & 1.089 & 0.041 \\
\hline 2 & 0.1 & 0.25 & 1.851 & 0.034 \\
\hline 3 & 0.1 & 0.5 & 2.541 & 0.061 \\
\hline 4 & 0.25 & 0.1 & 2.902 & 0.052 \\
\hline 5 & 0.25 & 0.25 & 3.553 & 0.071 \\
\hline 6 & 0.25 & 0.5 & 6.091 & 0.095 \\
\hline 7 & 0.5 & 0.1 & 3.418 & 0.064 \\
\hline 8 & 0.5 & 0.25 & 4.021 & 0.066 \\
\hline 9 & 0.5 & 0.5 & 4.671 & 0.083 \\
\hline
\end{tabular}
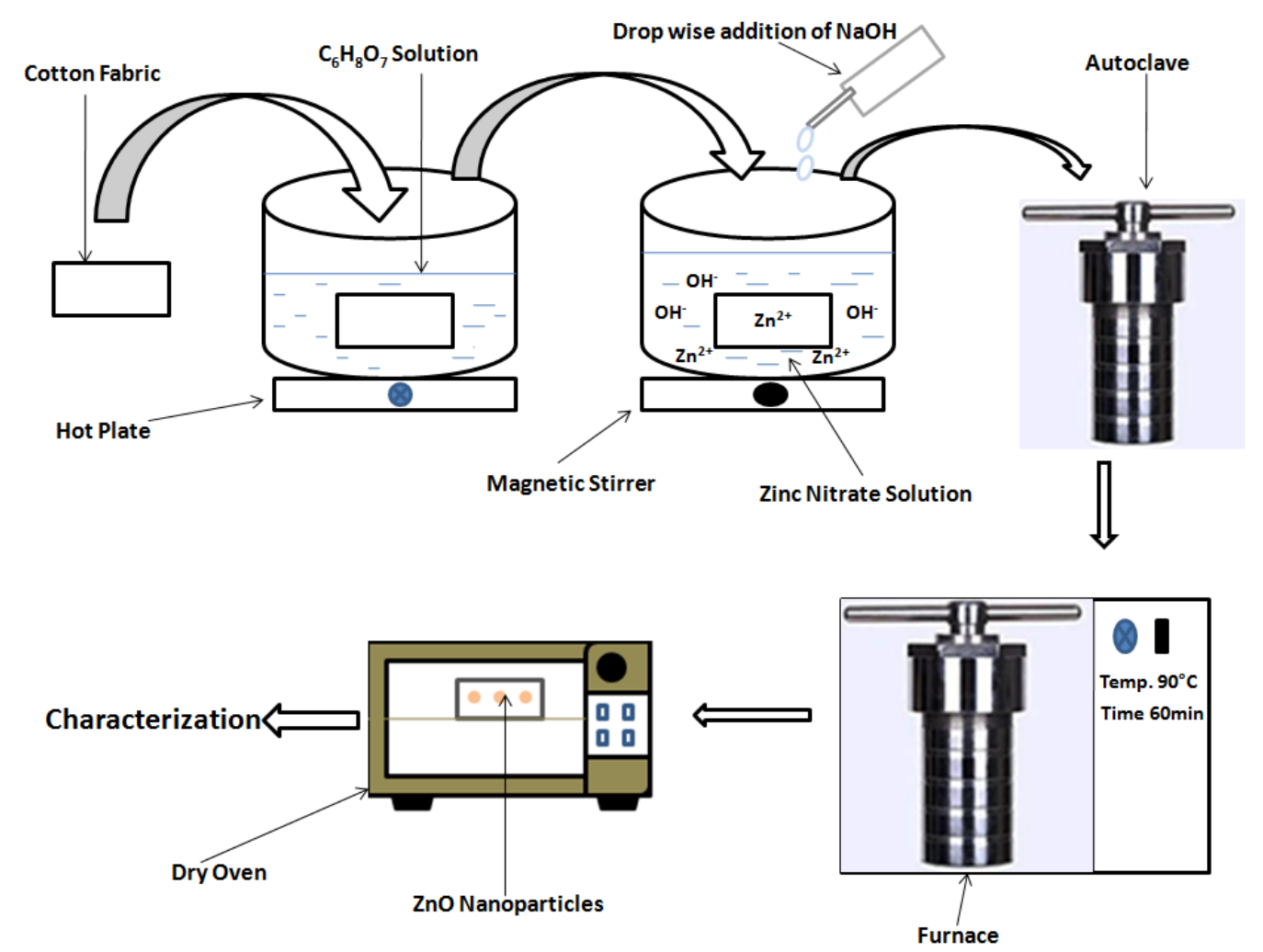

Figure 1. Schematic diagram of in-situ synthesis on $\mathrm{ZnO}$ nanoparticles onto the cotton fabrics.

\subsection{Characterization and Functional Properties}

An induced coupled plasma atomic emission spectrometer (ICP AES, Optima 7300 DV, Perkin-Elmer Corporation, Waltham, MA, USA) was used to analyze the Zn contents. The developed samples of $\mathrm{ZnO}$ NPs loaded cotton fabric of weight $0.1 \mathrm{~g}$ were treated with $8 \mathrm{~mL}$ of concentrated $\mathrm{HNO}_{3}(65 \%)$ until the cotton completely dissolved. After that, obtained solutions were transferred to a $100 \mathrm{~mL}$ volumetric flask and then diluted with deionized water.

The surface of the $\mathrm{ZnO}$ coated textile was visualized employing Schottky type field emission gun scanning electron microscope (SEM) Quanta 200 FEG (FEI company, Hillsboro, OR, USA). Aiming to avoid charging effects of the insulating samples, they were investigated under a water vapor atmosphere in the low vacuum regime of $80 \mathrm{~Pa}$ utilizing a large field detector.

XRD patterns were recorded employing D8 Discover X-ray diffractometer (Bruker ASX $\mathrm{GmbH}$, Billerica, MA, USA). Measurements were performed in the range 5.0-90.0 with 
a step size of $0.027^{\circ}$ and auto-repeat function enabled. Diffractograms were processed with the DIFFRAC.EVA software. The size of nano crystallites was calculated by the Scherrer Equation (8) [46].

$$
\mathrm{d}=\frac{\mathrm{K} \lambda}{\beta \operatorname{Cos} \theta},
$$

where $\mathrm{K}$ indicates the Scherrer constant (0.89), is the wavelength of $X$-rays, $\theta$ represents the Bragg diffraction angle, and $\beta$ is full width at half maximum of the peak of $\mathrm{ZnO}$ nanoparticles.

Fourier Transform Infrared (FTIR) spectra were collected at room temperature using a "VERTEX 70" (Bruker, Ettlingen, Germany) spectrometer. Scans were made in attenuated total reflectance (ATR) mode using ZnSe crystal in a range from 4000 to $600 \mathrm{~cm}^{-1}$ with a resolution of $4 \mathrm{~cm}^{-1}$ and averaged over 16 scans.

The UV protection capability of obtained samples was judged using Varian CARY 1E UV/VIS spectrophotometer containing a DRA-CA-301 integrating sphere and solar screen software in the range $280-400 \mathrm{~nm}$ as per AATCC $183-2000$ standard. According to this standard test method, the ultraviolet radiation transmitted or blocked by textile fabrics is determined for the samples intended to be used for UV protection. The percentage of UV radiation transmission was measured. Standard conditions of $20 \pm 2{ }^{\circ} \mathrm{C}$ temperature and $65 \pm 2 \%$ relative humidity were used for sample handling. The averaged value of four measurements was used. Equation (9) was used for UV protection factor (UPF) calculation:

$$
\mathrm{UPF}=\frac{\sum_{280 \mathrm{~nm}}^{400 \mathrm{~nm}} \mathrm{E}_{\lambda} \mathrm{S}_{\lambda} \Delta_{\lambda}}{\sum_{280 \mathrm{~nm}}^{400 \mathrm{~nm}} \mathrm{E}_{\lambda} S_{\lambda} \mathrm{T}_{\lambda} \Delta_{\lambda}}
$$

where

$\mathrm{E}_{\lambda}=$ solar spectra irradiance

$\mathrm{S}_{\lambda}=$ relative erythemal spectral response

$\Delta_{\lambda}=$ measured wavelength region in $\mathrm{nm}$

$\mathrm{T}_{\lambda}=$ average spectral transmittance $(\%)$

Antibacterial performance of the fabrics was evaluated for Gram-negative E. coli and Gram-positive S. aureus bacteria organisms, as per quantitative test method AATCC 100-2012. This test method defines the process of obtaining the values for calculation of the decrease of bacteria colony amount, which appeared after 24-h exposure.

Samples with and without $\mathrm{ZnO}$ NPs were cut into pieces of $4.8 \pm 0.1 \mathrm{~cm}$ diameter and stored in a $250 \mathrm{~mL}$ conical flask containing $1 \mathrm{~mL}$ of bacterial inoculums. After $24 \mathrm{~h}$ of the contact period, the solution was diluted in a nutrient bath. Further, the agar plates were prepared by putting the obtained solution into the agar plates. Then, the agar plates were incubated for $24 \mathrm{~h}$ at $37 \pm 2{ }^{\circ} \mathrm{C}$. The numbers of bacterial colonies that appeared in the agar plate were counted. The Equation (10) was used to calculate the bacterial reduction, expressed as a percentage.

$$
\mathrm{R} \%=\frac{\mathrm{A}-\mathrm{B}}{\mathrm{A}} \times 100,
$$

where A is the amount of bacteria colonies recovered from the control sample; B is the amount of bacteria colonies from the treated cotton sample, and $\mathrm{R} \%$ is the decrease of bacteria colonies in percent.

The photo catalytic ability of the ZnO NPs treated samples was examined based on the degradation of methyl orange under the influence of sunlight for $24 \mathrm{~h}$. To perform the experiment, samples were placed in a $0.01 \%$ (weight/volume) solution of $\mathrm{MO}$ for $1 \mathrm{~h}$ in order to reach the equilibrium. Afterward, the samples were left to dry in the laboratory ambient. Finally, samples were exposed to sunlight illumination for different periods and the colour difference was assessed according to CIE Lab colour space using Equation (11) [47].

$$
\Delta \mathrm{E}=\sqrt{\left(\Delta \mathrm{L}^{*}\right)^{2}+\left(\Delta \mathrm{a}^{*}\right)^{2}+\left(\Delta \mathrm{b}^{*}\right)^{2}}
$$




$$
\begin{aligned}
\Delta \mathrm{L}^{*} & =\mathrm{L}_{1}^{*}-\mathrm{L}_{2}^{*}, \\
\Delta \mathrm{a}^{*} & =\mathrm{a}_{1}^{*}-\mathrm{a}_{2}^{*}, \\
\Delta \mathrm{b}^{*} & =\mathrm{b}_{1}^{*}-\mathrm{b}_{2}^{*},
\end{aligned}
$$

where $\Delta \mathrm{E}$ is the colour change, $\mathrm{L}^{*}$ lightness, $\mathrm{a}^{*}$, and $\mathrm{b}^{*}$ are the chromaticity coordinates; which represent the colour directions: $+a^{*}$ is the red axis, $-a^{*}$ is the green axis, $+b^{*}$ is the yellow axis, and $-b^{*}$ is the blue axis.

\section{Results}

\subsection{Induced Coupled Plasma Atomic Emission Spectroscopy (ICP-AES) Analysis}

Cotton fabric samples with deposited $\mathrm{ZnO}$ NPs were analyzed with the help of ICPAES to determine the optimized and most effective molar concentrations of chemical precursors. From Table 1 and Figure 2 it can be seen that molar concentrations of chemical precursors have a great effect on the amount of $\mathrm{Zn}$ contents synthesized. The maximum amount of Zn contents was observed for sample 6, which showed Zn contents $6.091 \mathrm{~g} / \mathrm{kg}$. The optimal concentrations of precursors for these experiments are $0.25 \mathrm{M} \mathrm{Zn}\left(\mathrm{NO}_{3}\right)_{2} \cdot 6 \mathrm{H}_{2} \mathrm{O}$ and $0.5 \mathrm{M} \mathrm{NaOH}$. The calculated probability values ( $p$ values), as shown in Tables S1 and $\mathrm{S} 2, \mathrm{Zn}\left(\mathrm{NO}_{3}\right)_{2} \cdot 6 \mathrm{H}_{2} \mathrm{O}=0.00009$ and $\mathrm{NaOH}=0.00008$ are less than 0.05 , which proved the significant effect of precursors molar concentration on the amount of $\mathrm{Zn}$ contents synthesized, which indicates strong evidence against the null hypothesis. Moreover, Pearson correlation coefficients for $\mathrm{Zn}\left(\mathrm{NO}_{3}\right)_{2} \cdot 6 \mathrm{H}_{2} \mathrm{O}=0.572$ and $\mathrm{NaOH}=0.576$ (Tables S1 and S2) indicates the positive correlation between molar concentration of precursors and the amount of $\mathrm{Zn}$ contents synthesized.

\subsection{Surface Morphology}

The differences in the surface morphology of the pristine cotton sample and the $\mathrm{ZnO}$ NPs-loaded sample are seen in the SEM micrographs depicted in Figure 3 and Figure S1. The pristine cotton sample (Figure $3 \mathrm{~A}, \mathrm{~B}$ ) has some micro-roughness on the surface, which eventually increases the adhesion of the ZnO NPs during the chemical deposition. Conversely, the hydrothermal process treated cotton fabric (Figure 3C-E) becomes decorated with a ZnO NPs layer that was deposited with the optimized process No. 6 (Table 1). These ZnO NPs are distributed homogeneously on the surface of the sample 6 . The presences of the $\mathrm{ZnO} N$ Ps on the surface of sample 6 are due to the attraction between active functional groups of cellulose and $\mathrm{ZnO}$ NPs [48], which results in the cotton surface coverage by a layer of $\mathrm{ZnO} N$ Ps.

\subsection{XRD Analysis}

Figure 4 shows the $X$-ray diffraction pattern of pristine cotton and after one-step hydrothermal process treated sample 6 . From the XRD it can be seen that pristine cotton has multiple peaks at $2 \theta=14.9^{\circ}, 16.6^{\circ}$, and $22.7^{\circ}$, which correspond to planes (1-10), (110), and (002), respectively. These are the characteristic diffraction peaks of cellulose (JCPDS 03-0226) [49]. On the other hand, the XRD pattern for ZnO NPs coated sample 6 shows that there are extra diffraction peaks at $2 \theta=32.1^{\circ}, 34.7^{\circ}, 36.5^{\circ}, 47.8^{\circ}, 56.7^{\circ}, 63.1^{\circ}$, and $68.1^{\circ}$. The characteristic peaks in XRD pattern polycrystalline hexagonal wurtzite (joint committee on the powder diffraction standard No. 36-1451) ZnO NPs were attributed to (1 $\left.\begin{array}{lll}0 & 0\end{array}\right),\left(\begin{array}{lll}0 & 0 & 2\end{array}\right),\left(\begin{array}{lll}1 & 0 & 1\end{array}\right),\left(\begin{array}{lll}1 & 0 & 2\end{array}\right),\left(\begin{array}{lll}1 & 1 & 0\end{array}\right),\left(\begin{array}{lll}1 & 0 & 3\end{array}\right)$, and (1 112$)$ crystallographic plane orientations, respectively [50]. The crystallite size was calculated employing Equation (8) for $\left(\begin{array}{lll}1 & 0 & 1\end{array}\right)$ reflex. Samples with loaded ZnO NPs had crystallite sizes in the range 20.3-22.4 nm. Other studies report various crystallite sizes from 4 to $35 \mathrm{~nm}$ (Table 2). 

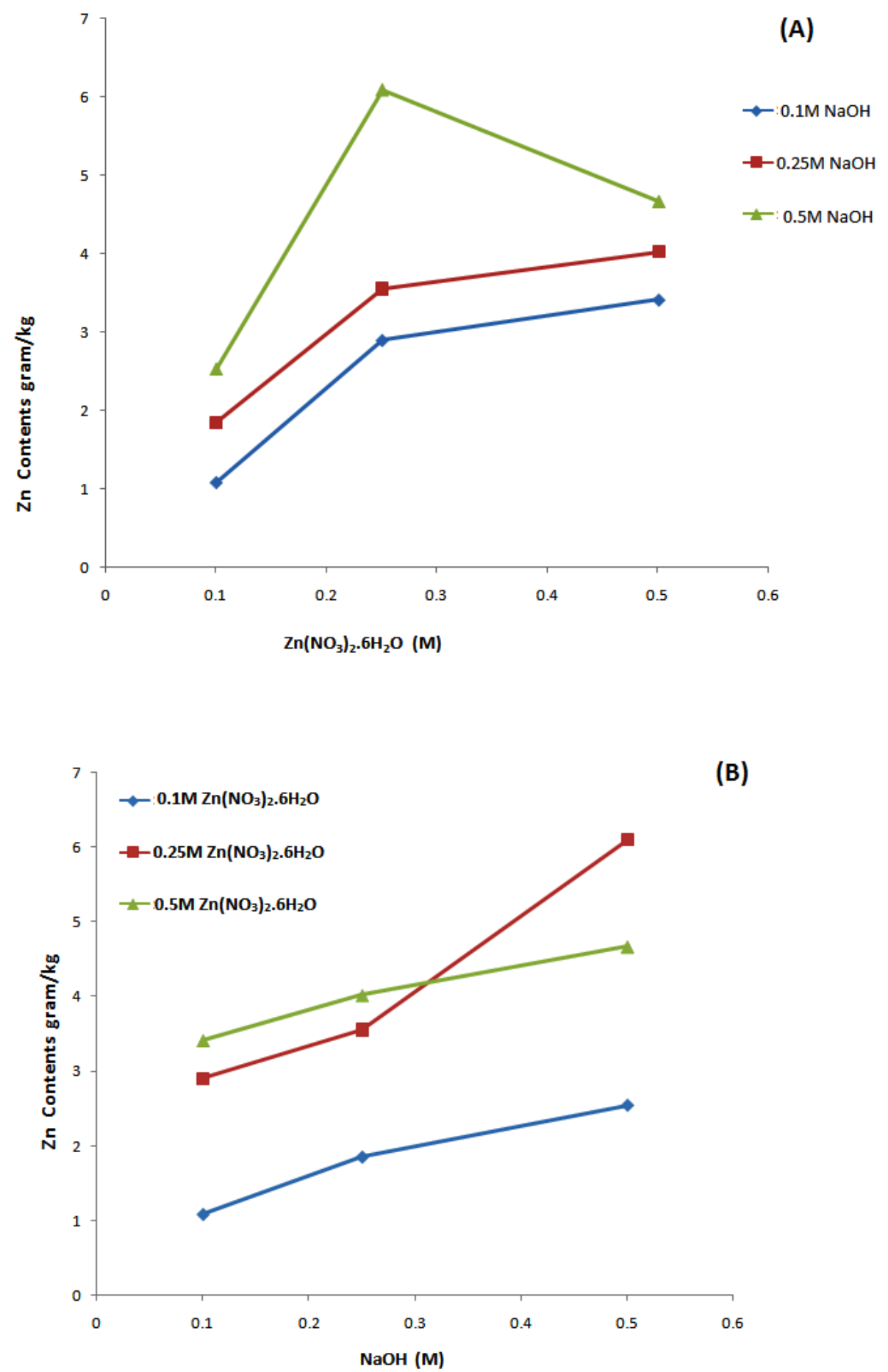

Figure 2. Deposited amount of $\mathrm{Zn}$ content versus precursor concentration: (A) $\mathrm{Zn}\left(\mathrm{NO}_{3}\right)_{2} \cdot 6 \mathrm{H}_{2} \mathrm{O}$, (B) $\mathrm{NaOH}$. 


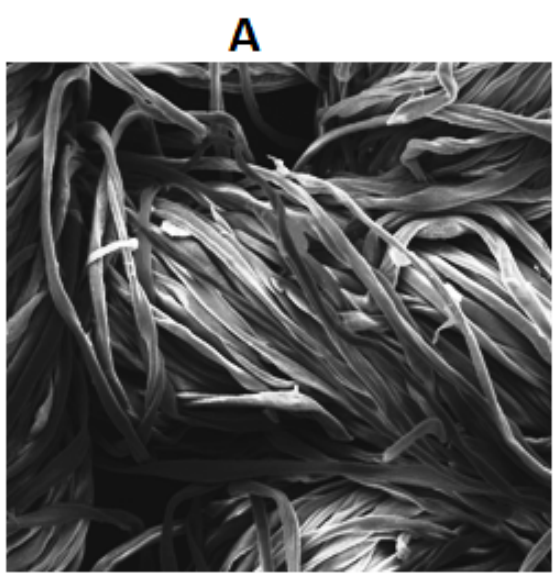

$200 \mu \mathrm{m}$

C

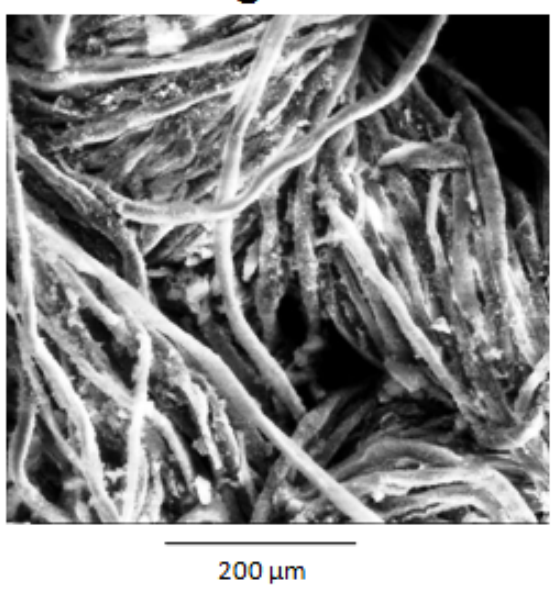

B

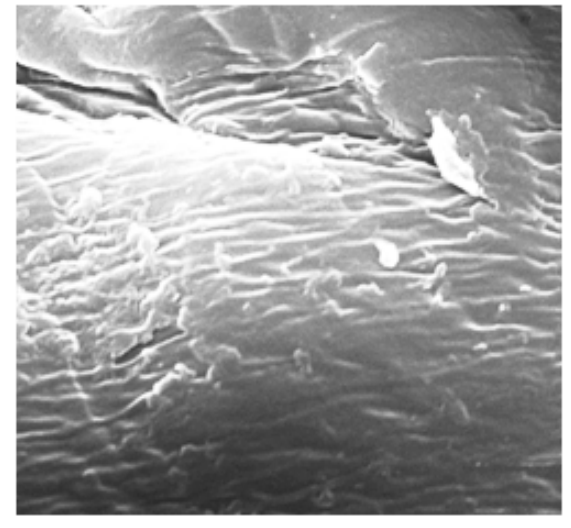

$5 \mu \mathrm{m}$

D

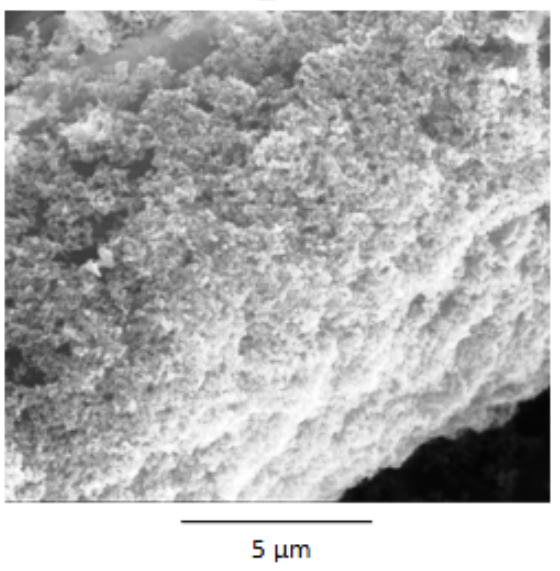

\section{E}

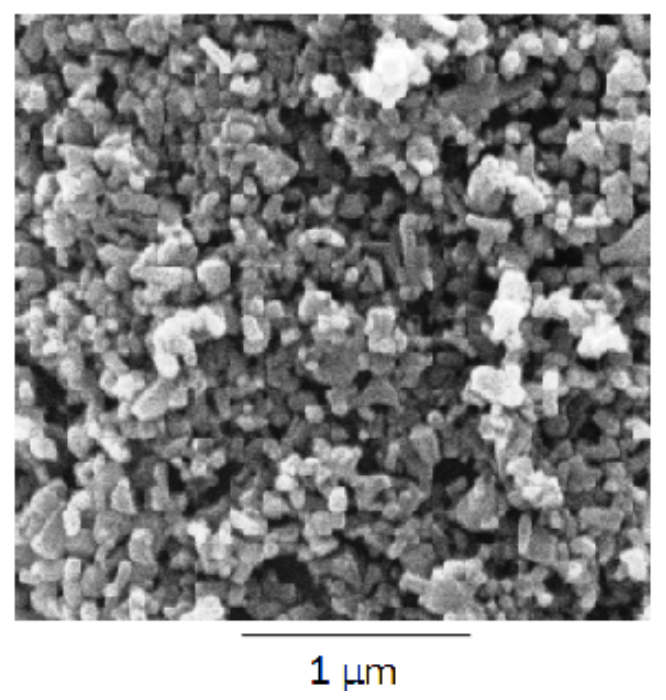

Figure 3. SEM images (A,B) pristine cotton. (C-E) highest amount of Zn contents, i.e., $6.091 \mathrm{~g} / \mathrm{kg}$ (Sample 6). 


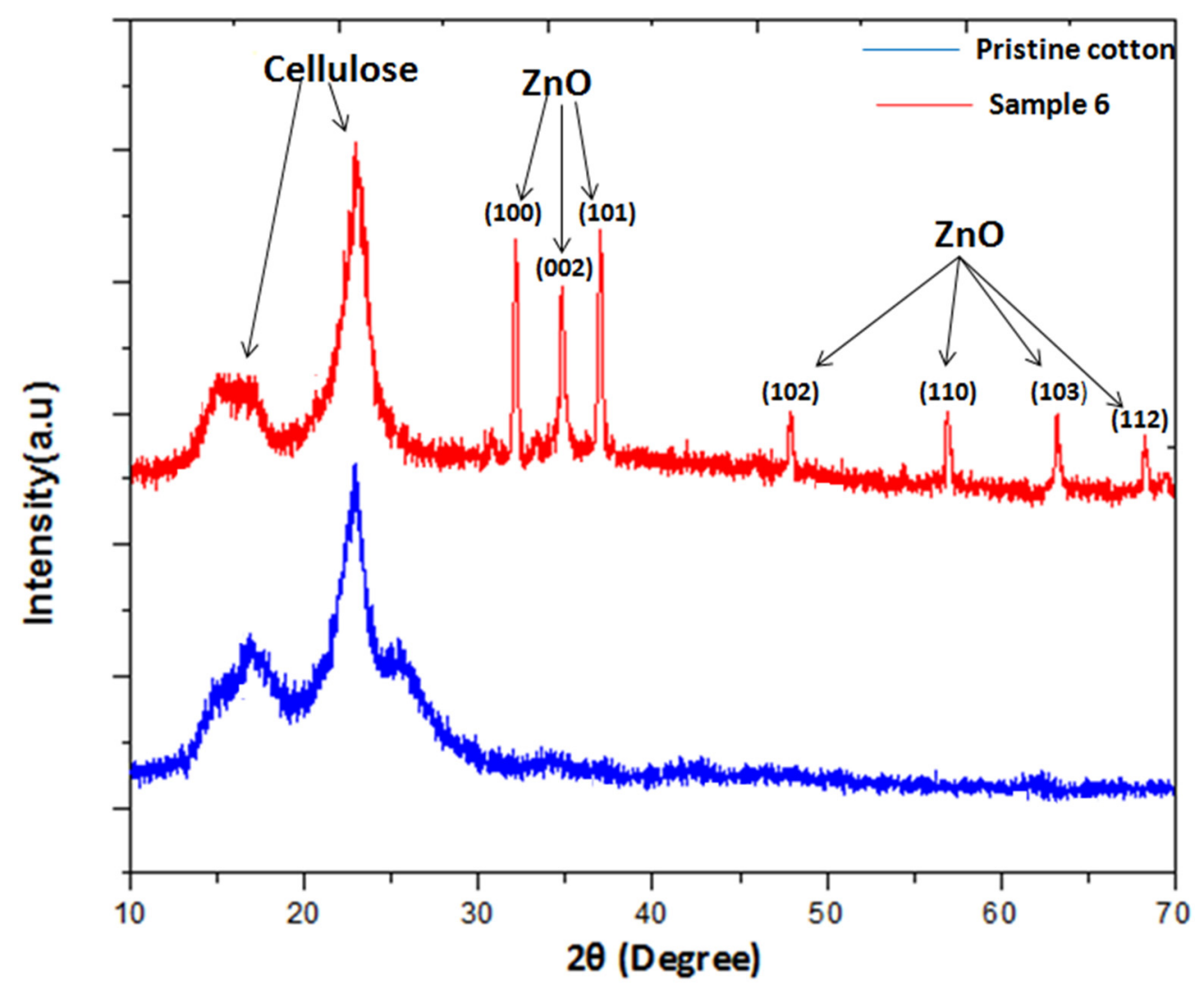

Figure 4. XRD diffractogram of pristine cotton and sample (6).

Table 2. Comparison of crystallite sizes of ZnO NPs.

\begin{tabular}{|c|c|c|c|}
\hline Method & Precursors & Crystallite Size in nm (XRD) & Ref. \\
\hline One Step Hydrothermal & $\mathrm{Zn}\left(\mathrm{NO}_{3}\right)_{2} \cdot 6 \mathrm{H}_{2} \mathrm{O}, \mathrm{NaOH}$ & $20.3-22.4$ & This study \\
\hline Solvothermal & $\begin{array}{l}\mathrm{Zn}\left(\mathrm{NO}_{3}\right)_{2} \cdot 6 \mathrm{H}_{2} \mathrm{O} \\
\text { tetramethylammonium hydroxide }\end{array}$ & 4.1 & [51] \\
\hline Precipitation Method & Zinc acetate, Diethylene glycol & $5-35$ & [52] \\
\hline Solvothermal & Zinc acetate, Triethanolamine & $33 \pm 2$ & [53] \\
\hline
\end{tabular}

\subsection{FTIR Analysis}

The FTIR spectra were collected to examine the grafting information of in-situ deposited ZnO NPs on the surface of cotton fabric after a one-step hydrothermal process. The FTIR spectra of pristine cotton fabric and sample 6 are shown in Figure 5. The main detected bands at $3308 \mathrm{~cm}^{-1}\left(\mathrm{OH}\right.$ stretch) $2887 \mathrm{~cm}^{-1}(\mathrm{CH}$ stretching $), 1632 \mathrm{~cm}^{-1}(\mathrm{C}=\mathrm{O}$ stretching) [54], $1427 \mathrm{~cm}^{-1}$ (C-H wagging), $1314 \mathrm{~cm}^{-1}$ (C-H bending), and $1029 \mathrm{~cm}^{-1}$ (C-O stretch) are indicated in Figure 5 and all can be attributed to the cotton [55,56]. It can be seen from Figure 5 that after the one-step hydrothermal process the spectra of sample 6 have the same shape and characteristic peaks as one untreated cotton. The visible difference is the intensity of the peaks affirming that the cotton surface is covered by ZnO NPs [57,58]. 


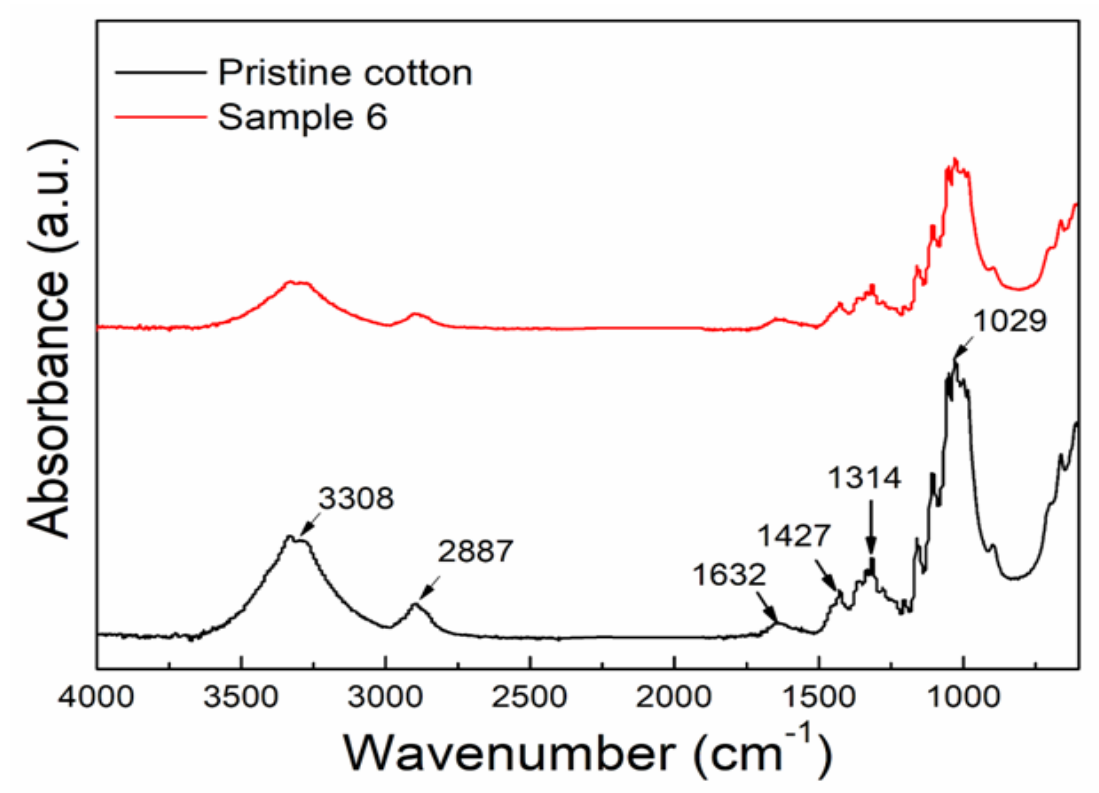

Figure 5. FTIR absorbance spectra of pristine cotton and sample (6).

\subsection{UV Protection Factor}

The spectrum of sunlight contains UV radiations, which have three main types: ultraviolet $A, B$, and $C$ radiation (UVA, UVB, and UVC, respectively) [59]. The UVC covers the wavelengths from 100 to $280 \mathrm{~nm}$, UVB from 280 to $315 \mathrm{~nm}$, and UVA from 315 to $400 \mathrm{~nm}$. UVC radiation is mostly absorbed by the ozone layer in the atmosphere and does not arrive on earth. The UVA radiation is the most harmful of all mentioned and causes skin cancer, sunburn, acne, and damages the DNA [60-62]. The ability of the fabric to provide skin shielding against harmful radiation is quantified as UV protection factor (UPF) [63]. The UPF value describes how much of the UV rays the fabric transmits. UPF values and protection categories of the fabric categorized by The Australian Standardization Institute is presented in Table S3 [64].

UV protective factor (Figure 6) and UVA and UVB blocking (Figure 7) of the one-step in-situ ZnO NPs loaded cotton is demonstrated. The initial cotton fabrics before loading had a value of only 4.82 UPF units, while the UVA and UVB blocking percentage values for the initial cotton fabrics were $72.99 \%$ and $77.89 \%$, respectively. From the measured values it can be seen that after ZnO NPs loading UPF values as well as UVA and UVB blocking percentage increased, which can be explained by the UV absorption capacity of ZnO NPs on cotton fabric [16]. Furthermore, the highest UPF had a sample with highest Zn contents $6.091 \mathrm{~g} / \mathrm{kg}$ (optimized sample 6), which was 129.97, which indicates that UPF values are strongly related to the amount of ZnO NPs content deposited onto the textile fabric. The Figure 6 inset indicates that UPF value increased with increased amount of Zn contents loaded on to the fabric. The sample with the highest Zn contents $6.091 \mathrm{~g} / \mathrm{kg}$ (optimized sample 6) showed UVA and UVB blocking percentages as $97.11 \%$ and $99.12 \%$ respectively. Moreover Figure 7 inset shows that the UVA and UVB blocking percentages were increased with amount of $\mathrm{Zn}$ contents loaded on to the fabric. Calculated Pearsons correlation coefficient value (0.98) (Table S4) shows strong positive linear correlation between deposited amount of Zn contents and UPF value. Furthermore, the $p$ value $0.0003<0.05$ (Table S4) demonstrates that Zn contents amount influence the UPF value. UV blocking relation to the amount of $\mathrm{Zn}$ contents (Figure 7 inset) demonstrates that the increase of the deposited amount of Zn contents leads to both UVA blocking and UVB blocking percentage increase. The $p$ values $2.6 \times 10^{-12}<0.05$ and $5.6 \times 10^{-13}<0.05$ (Tables S5 and S6) determine that the synthesized amount of $\mathrm{Zn}$ contents on to the fabric has a significant effect on UV blocking. 


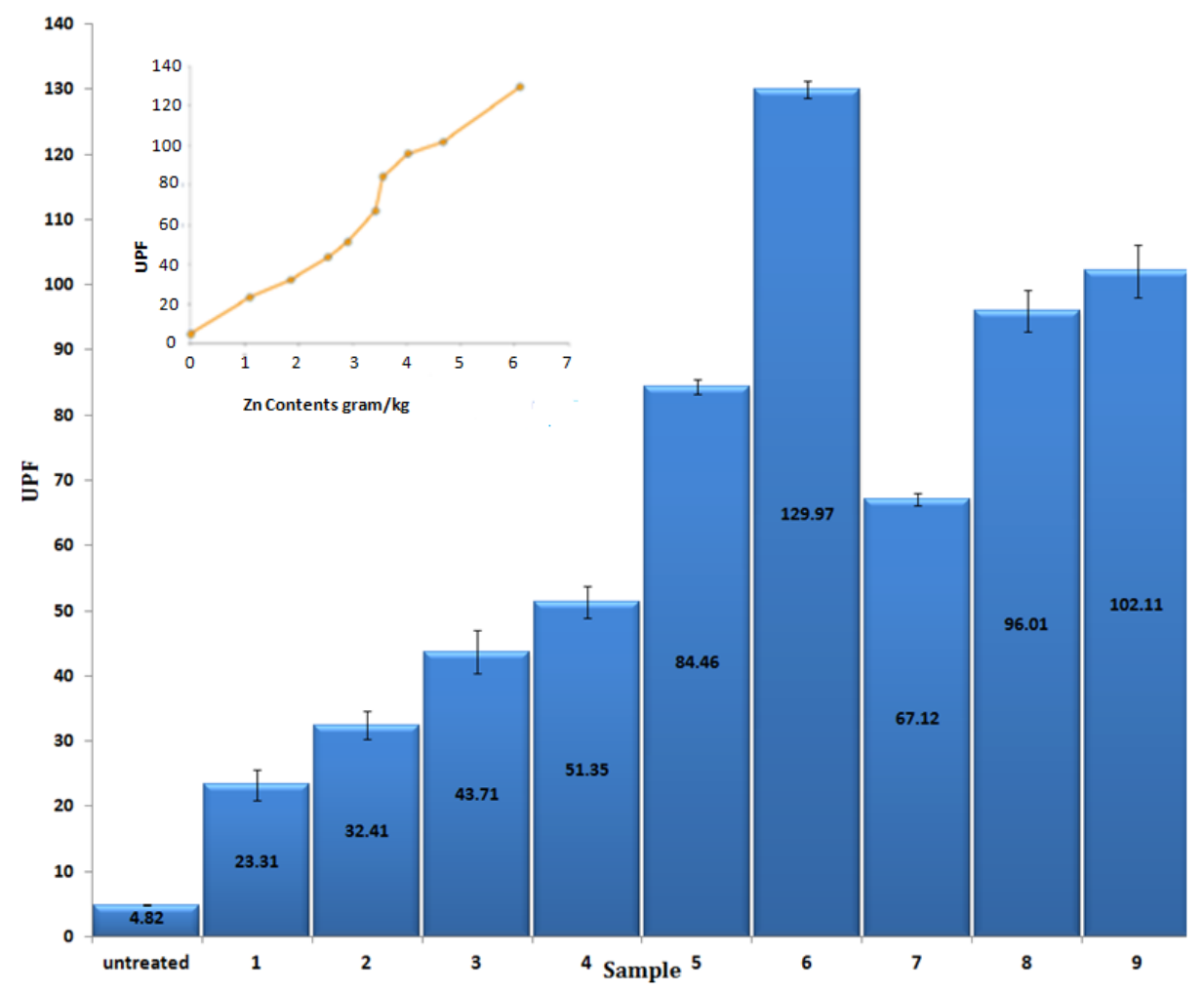

Figure 6. UPF values of untreated and $\mathrm{ZnO}$ nanoparticles loaded on cotton fabrics. The inset shows dependence of UPF values on the amount of $\mathrm{Zn}$ contents.

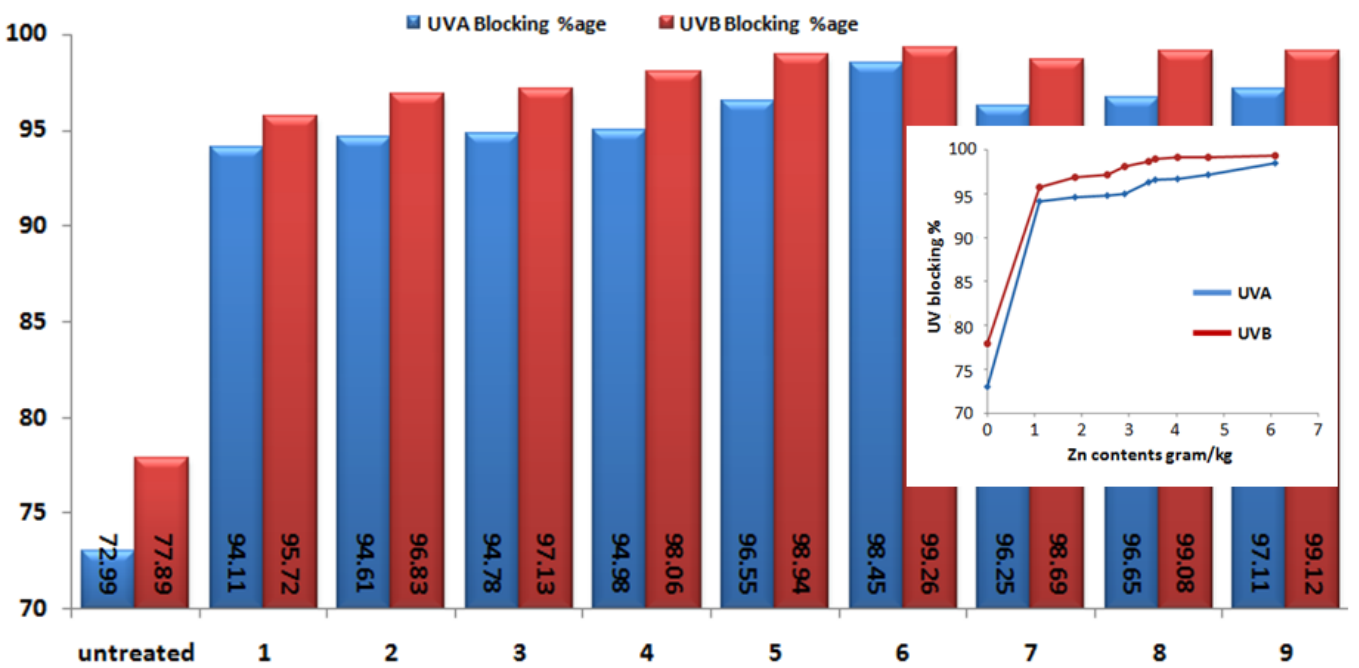

Figure 7. UVA and UVB blocking percentage of initial and cotton with ZnO NPs. The inset shows UV blocking percentage versus amount of $\mathrm{Zn}$ contents.

ZnO NPs highly absorb UV, moreover, the high refractive index of ZnO NPs has a great role in high UPF value and UV blocking. The high refraction ZnO NPs causes the scattering of UV light, therefore UV light is not transmitted to human skin [65]. Table 3 shows the comparisons of current results with literature. 
Table 3. Comparison of UPF, UVA, and UVB blocking percentage.

\begin{tabular}{|c|c|c|c|c|c|c|c|}
\hline Precursors & $\begin{array}{l}\text { Size of } \mathrm{ZnO} \\
\text { NPs }\end{array}$ & Method & UPF & UVA Blocking & UVB Blocking & $\begin{array}{l}\text { Mass Load } \\
\mathrm{Zn}(\mathrm{g} / \mathrm{kg})\end{array}$ & Ref. \\
\hline $\mathrm{Zn}\left(\mathrm{NO}_{3}\right)_{2} \cdot 6 \mathrm{H}_{2} \mathrm{O}, \mathrm{NaOH}$ & $\begin{array}{l}20.3-22.4 \\
\text { (by XRD) }\end{array}$ & $\begin{array}{c}\text { One step } \\
\text { hydrothermal }\end{array}$ & 129.97 & 97.11 & 99.12 & 6.091 & This work \\
\hline $\mathrm{ZnCl}_{2}, \mathrm{NaOH}$ & - & $\begin{array}{l}\text { One step } \\
\text { hydrothermal }\end{array}$ & 80.2 & 92.6 & 99.1 & 0.71 & [18] \\
\hline $\begin{array}{c}\mathrm{Zn}\left(\mathrm{NO}_{3}\right)_{2} \cdot 6 \mathrm{H}_{2} \mathrm{O} \\
\mathrm{C}_{6} \mathrm{H}_{12} \mathrm{~N}_{4}\end{array}$ & $\begin{array}{l}1760 \pm 120 \\
(\text { by SEM) }\end{array}$ & $\begin{array}{l}\text { Two step } \\
\text { hydrothermal }\end{array}$ & 157.8 & 99.54 & 99.69 & - & [48] \\
\hline $\begin{array}{c}\mathrm{Zn}\left(\mathrm{NO}_{3}\right)_{2} \cdot 6 \mathrm{H}_{2} \mathrm{O} \text {, } \\
\text { Hexamethyleneteraamine }\end{array}$ & $\begin{array}{l}55 \pm 6.1 \\
(\text { by SEM) }\end{array}$ & $\begin{array}{c}\text { Two step } \\
\text { hydrothermal }\end{array}$ & 114 & 95.8 & 99.3 & - & [66] \\
\hline
\end{tabular}

\subsection{Antibacterial Performance}

Antibacterial performance of ZnO NPs loaded cotton fabrics was evaluated according to the colony count method (Table 4, Figure 8). The antibacterial activity of ZnO NPs loaded samples is increased with the increased amount of synthesized ZnO NPs on the cotton fabric for both Gram-negative E. coli and Gram-positive S. aureus bacteria. Sample 9 showed a $100 \%$ reduction only for $S$. aureus bacteria, while the optimized sample 6 showed a $100 \%$ bacterial reduction for both E. coli and S. aureus bacteria.

Table 4. Antibacterial performance of $\mathrm{ZnO}$ nanoparticles loaded cotton fabrics.

\begin{tabular}{|c|c|c|c|c|}
\hline Sample No. & Zn Contents (g/kg) & $\begin{array}{c}\text { S. aureus } \\
\text { (Reduction \%) }\end{array}$ & $\begin{array}{c}\text { E. coli } \\
\text { (Reduction \%) }\end{array}$ & Ref. \\
\hline 1 & 1.089 & 47.23 & 49.76 & \\
\hline 2 & 1.851 & 51.41 & 50.12 & \\
\hline 3 & 2.541 & 56.67 & 57.03 & \\
\hline 4 & 2.902 & 62.85 & 59.43 & This study \\
\hline 5 & 3.553 & 77.06 & 80.65 & \\
\hline 6 & 6.091 & 100.00 & 100.00 & \\
\hline 7 & 3.418 & 74.31 & 72.17 & \\
\hline 8 & 4.021 & 88.09 & 91.47 & \\
\hline 9 & 4.671 & 100.00 & 94.96 & \\
\hline Wet chemical method & - & $>99.99$ & 80 & [67] \\
\hline Solochemical process & - & 100 & - & [68] \\
\hline Ultrasonic Irradiation Process & - & 100 & 100 & [69] \\
\hline
\end{tabular}

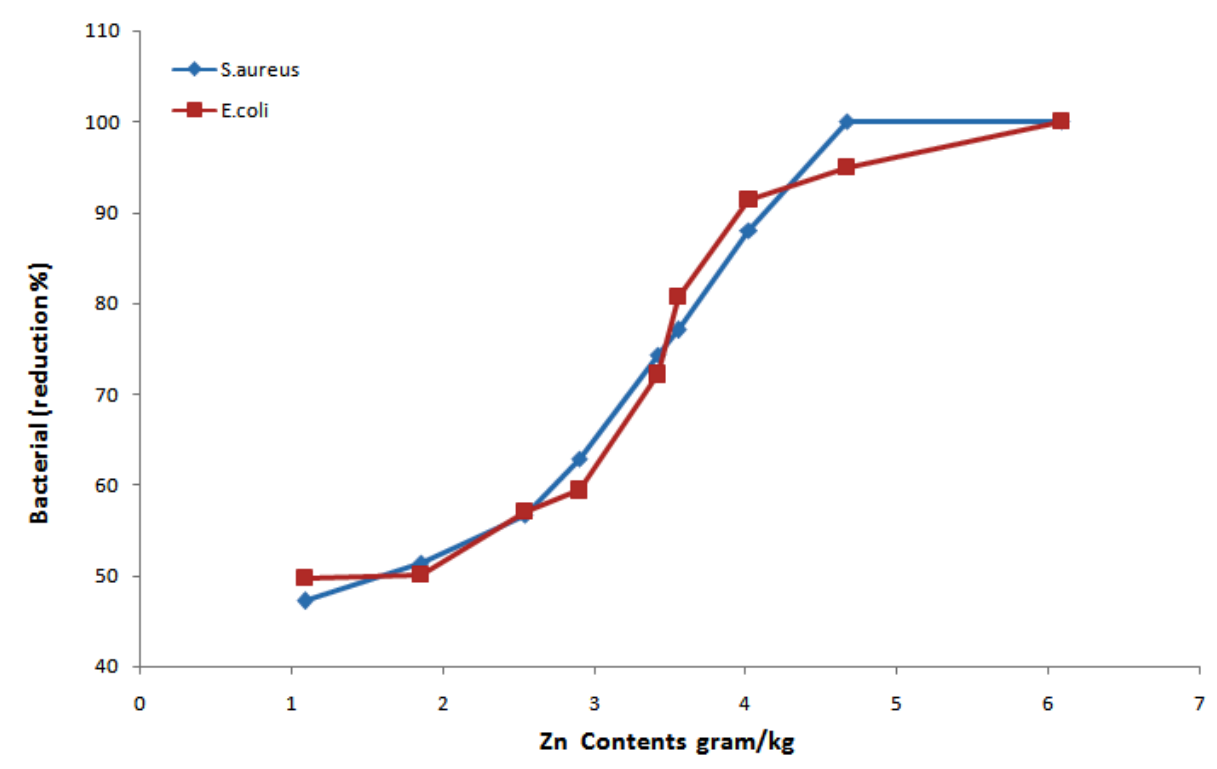

Figure 8. Bacterial reduction efficiency dependence on the $\mathrm{Zn}$ content.

The antibacterial activity of $\mathrm{ZnO}$ NPs is due to the deactivation of vital enzymes caused by interacting with the thiol group and ZnO NPs, as well as being involved with 
the disruption of the bacteria membranes by $\mathrm{ZnO}$ NPs $[17,56]$. Moreover, as the ZnO NPs attach to the bacterial cell wall, it might result in an increased concentration of $\mathrm{Zn}^{2+}$ cations in the bacterial cytoplasm, which causes the death of bacterial cells [70]. Pearson correlation coefficient for S. aureus reduction and E. coli reduction percentage was calculated as 0.95 and 0.94 (Tables S7 and S8), respectively, which reflects the strong correlation with the amount of $\mathrm{Zn}$ contents deposited on the fabric surface. Furthermore, calculated $p$-values (Tables S7 and S8) $1.7 \times 10^{-6}$ and $1.6 \times 10^{-6}<0.05$ indicate the significant effect of $\mathrm{Zn}$ amount on the bacterial reduction for both S. aureus and E. coli.

\subsection{Photo Catalytic Ability}

The photo catalytic ability of ZnO NPs loaded cotton fabrics was assessed according to the measurement of the colour change $(\Delta \mathrm{E})$ of methyl orange before and after exposure to sunlight illumination. Figure 9 shows the change in colour of the initial fabrics and $\mathrm{ZnO}$ NPs loaded cotton fabric samples and the schematic mechanism of photo catalytic activity in the Figure $10[16,71]$. It can be noticed that the initial fabric sample has little colour change $(\Delta \mathrm{E})$, while on the other hand, the $\mathrm{ZnO}$ loaded samples demonstrated high photo catalytic activity. The photo catalytic performance of ZnO NPs loaded cotton fabric samples increased with the increased amount of ZnO NPs. In another study, Javed et al. reported the colour difference $(\Delta \mathrm{E}) 86.21$ for $\mathrm{ZnO}$ NPs loaded cotton fabrics using a sonochemical method [56].

The Figure 9 inset shows the maximum colour difference $(\Delta \mathrm{E}) 81.31$ observed for sample 6, having the maximum amount of $\mathrm{ZnO}$ NPs. These results are in line with the work by Sudrajat. H., demonstrating that the higher photo catalytic activity is obtained at higher amounts of $\mathrm{ZnO} N$ Ps [72]. The calculated Pearson correlation coefficient is 0.95 (Table S9), showing that $\Delta \mathrm{E}$ value has strong correlation with the amount of $\mathrm{Zn}$ contents synthesized. Furthermore, calculated $p$ value $0.9 \times 10^{-5}<0.05$ (Table S9) prove that the amount of $\mathrm{Zn}$ contents synthesized on to the fabric surface have a significant effect.

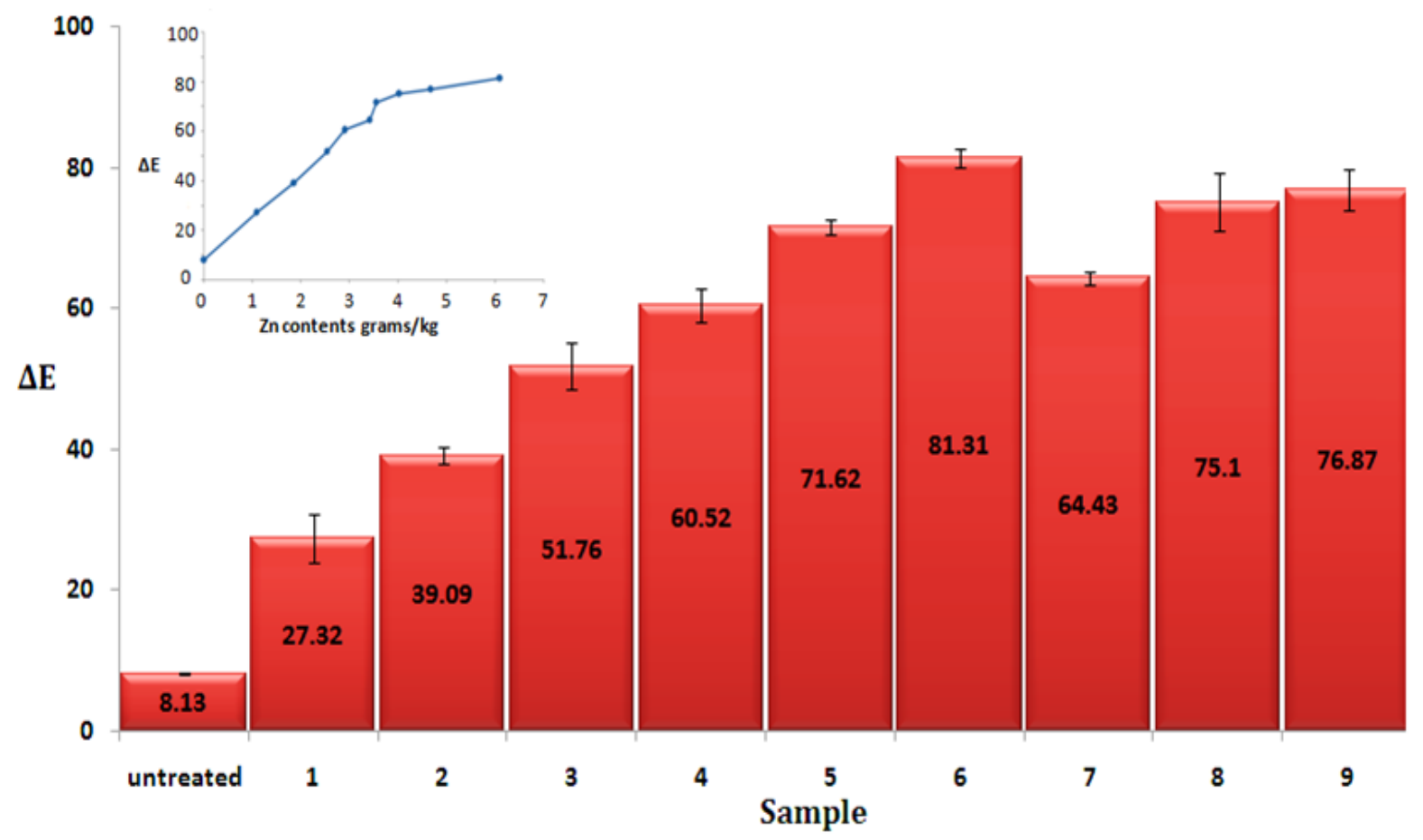

Figure 9. Photocatalytic properties (colour difference $\Delta \mathrm{E}$ ) of untreated and $\mathrm{ZnO}$ nanoparticles loaded cotton fabrics. The inse $t$ shows colour difference $(\Delta \mathrm{E})$ dependence on the $\mathrm{Zn}$ content. The line is for eye guidance. 


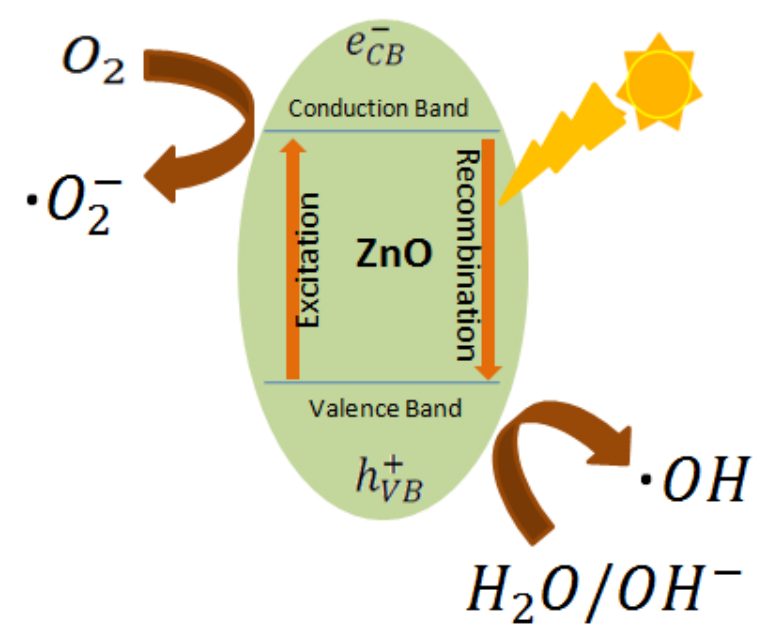

Figure 10. Schematic mechanism of photocytalytic activity.

As compared to untreated cotton fabric, the higher photo catalytic activity of $\mathrm{ZnO}$ NPs loaded cotton fabrics is because of ZnO NPs on the surface of the cotton fabrics, since $\mathrm{ZnO}$ NPs cause degradation of the dye molecules by photo catalytic reactions [73]. In the photo-catalytic mechanism by ZnO NPs, two photochemical reactions "oxidation and reduction" occur. During these reactions reactive oxygen species " $\bullet \mathrm{OH}$ and $\bullet \mathrm{O}^{2-\prime}$ are produced. The $\bullet \mathrm{OH}$ radical has a vital role in oxidating the dye molecules [16]. The mechanism of dye degradation can be described by Equations (15)-(18).

$$
\begin{gathered}
\mathrm{ZnO}+\mathrm{hv} \rightarrow \mathrm{ZnO}\left(2 \mathrm{~h}^{+}+2 \mathrm{e}^{-}\right) \\
\frac{1}{2} \mathrm{O}_{2}+2 \mathrm{e}^{-} \rightarrow \mathrm{H}_{2} \mathrm{O}+2 \mathrm{OH}^{-} \\
2 \mathrm{OH}^{-}+\mathrm{h}^{+} \rightarrow 2 \bullet \mathrm{OH} \\
\bullet \mathrm{OH}+\text { dye } \rightarrow \text { degradation }
\end{gathered}
$$

\section{Conclusions}

In this work, modification of cotton textile was shown by the in-situ one-step hydrothermal synthesis of zinc oxide nanoparticles on pre-treated $100 \%$ cotton fabric. XRD analysis revealed pure wurtzite hexagonal crystals, with nano crystallite size of ZnO NPs between 5-6 nm, indicating the crucial role of the hydrothermal process at low temperature, i.e., $90^{\circ} \mathrm{C}$. SEM, ICP AES, and FTIR indicated the presence and grafting of ZnO NPs on the cotton fabrics. Varying the molar concentrations of the precursors' optimal conditions at $0.25 \mathrm{M}$ of $\mathrm{Zn}\left(\mathrm{NO}_{3}\right)_{2} \cdot 6 \mathrm{H}_{2} \mathrm{O}$ and $0.5 \mathrm{M}$ of $\mathrm{NaOH}$ yielded $6.091 \mathrm{~g} / \mathrm{kg}$ of $\mathrm{Zn}$ deposited on the fabric. The study revealed that the amount of $\mathrm{ZnO}$ NPs synthesized onto the cotton fabric directly correlated with the performance of functional properties. Antibacterial efficacy of $100 \%$ for E. coli and S. aureus bacteria was demonstrated. A UV protection factor reaching 130 for the sample containing the highest amount of Zn contents was demonstrated. Similarly, photo catalytic activity investigated using methyl orange confirmed the direct dependence of the colour change on the $\mathrm{ZnO}$ concentration. Our work demonstrates a feasible method for the high yield industrial loading of ZnO NPs on functional textile.

Supplementary Materials: The following are available online at https: / www.mdpi.com/article/ 10.3390/ma14143956/s1, Figure S1: SEM Images A and C Zn contents $4.671 \mathrm{gram} / \mathrm{kg}$ (Sample 9). B and D Zn contents 4.021 gram/kg (sample 8), Table S1: Statistical analysis by $t$-test (effect of $\mathrm{Zn}\left(\mathrm{NO}_{3}\right)_{2} \cdot 6 \mathrm{H}_{2} \mathrm{O}(\mathrm{M})$ on deposited amount of $\mathrm{Zn}$ Contents gram $/ \mathrm{kg}$ ), Table S2: statistical analyses by $t$-test (effect of $\mathrm{NaOH}(\mathrm{M})$ on deposited amount of $\mathrm{Zn}$ Contents gram $/ \mathrm{kg}$ ), Table S3: UPF value and protection category of the fabric categorized by The Australian standardization Institute, Table S4: Statistical analysis by $t$-test (effect of Zn Contents gram/kg on UPF value), Table S5: Sta- 
tistical analysis by $t$-test (effect of Zn Contents gram/kg on UVA Blocking\%), Table S6: Statistical analysis by $t$-test (effect of Zn Contents gram/ $\mathrm{kg}$ on UVB Blocking\%), Table S7: Statistical analysis by $t$-test (effect of Zn Contents gram/kg on S. aureus (Reduction\%), Table S8: Statistical analysis by $t$-test (effect of Zn Contents gram/kg on E. coli (Reduction\%), Table S9: Statistical analysis by $t$-test (effect of Zn Contents gram $/ \mathrm{kg}$ on $\Delta \mathrm{E}$ ).

Author Contributions: A.J. conceived, designed, performed experiments regarding $\mathrm{ZnO}$ nanoparticles, and wrote the manuscript. S.R., J.S. and J.W. supervised. S.R also acquired funding. A.T., T.T. and A.L. performed characterization for developed samples. T.T., S.R., A.T. and A.L. reviewed the manuscript and made corrections. All authors have read and agreed to the published version of the manuscript.

Funding: This research has received funding from the European Regional Development Fund (project No. 01.2.2-LMT-K-718-02-0011) under a grant agreement with the Research Council of Lithuania (LMTLT).

Institutional Review Board Statement: Not applicable.

Informed Consent Statement: Not applicable.

Data Availability Statement: Data is available on the request to the corresponding author.

Acknowledgments: A special thanks goes to project No. 01.2.2-LMT-K-718-02-0011 members Sigitas Tamulevičius, Andrius Vasiliauskas, Rimantas Gudaitis, Brigita Abakevičienè, Mindaugas Andrulevičius, Rasa Mardosaitė, Agnè Šulčiūtè, Mindaugas Juodènas, Aušrinè Jurkevičiūtė and Mindaugas Ilickas from Kaunas University of Technology for their technical assistance.A.J acknowledges the support by the ministry of education, youth and sports of Czech Republic and European Union- European structural and investment funds in the frames of operational programme research, development and education- project hybrid materials for hierarchical structures (HyHI, Reg.No.CZ.02.1.01/0.0/0.0/16_019/0000843) at Technical University of Liberec, Czech Republic.

Conflicts of Interest: The authors declare no conflict of interest.

\section{References}

1. Khan, I.; Saeed, K.; Khan, I. Nanoparticles: Properties, Applications and Toxicities. Arab. J. Chem. 2019, 12, 908-931. [CrossRef]

2. Jeevanandam, J.; Barhoum, A.; Chan, Y.S.; Dufresne, A.; Danquah, M.K. Review on Nanoparticles and Nanostructured Materials: History, Sources, Toxicity and Regulations. Beilstein J. Nanotechnol. 2018, 9, 1050-1074. [CrossRef] [PubMed]

3. Qu, X.; Alvarez, P.J.J.; Li, Q. Applications of Nanotechnology in Water and Wastewater Treatment. Water Res. 2013, 47, 3931-3946. [CrossRef] [PubMed]

4. Mohajerani, A.; Burnett, L.; Smith, J.V.; Kurmus, H.; Milas, J.; Arulrajah, A.; Horpibulsuk, S.; Kadir, A.A. Nanoparticles in Construction Materials and Other Applications, and Implications of Nanoparticle Use. Materials 2019, 12, 3052. [CrossRef]

5. Joshi, M.; Bhattacharyya, A. Nanotechnology-A New Route to High-Performance Functional Textiles. Text. Prog. 2011, 43, 155-233. [CrossRef]

6. Sawhney, A.P.S.; Condon, B.; Singh, K.V.; Pang, S.S.; Li, G.; Hui, D. Modern Applications of Nanotechnology in Textiles. Text. Res. J. 2008, 78, 731-739. [CrossRef]

7. Mandai, P.K.; Choi, K.; Min, S.G.; Lee, C.H. Application of Nanotechnology in Food Packaging: An Overview. Korean J. Food Sci. Anim. Resour. 2009, 29, 403-408.

8. Raut, S.B.; Vasavada, D.A.; Chaudhari, S.B. Nano Particles-Application in Textile Finishing. Man-Made Text. India 2010, 38, 31-36.

9. Lee, D.; Seo, Y.; Khan, M.S.; Hwang, J.; Jo, Y.; Son, J.; Lee, K.; Park, C.; Chavan, S.; Gilad, A.A.; et al. Use of Nanoscale Materials for the Effective Prevention and Extermination of Bacterial Biofilms. Biotechnol. Bioprocess Eng. 2018, 23, 1-10. [CrossRef]

10. Stankic, S.; Suman, S.; Haque, F.; Vidic, J. Pure and Multi Metal Oxide Nanoparticles: Synthesis, Antibacterial and Cytotoxic Properties. J. Nanobiotechnol. 2016, 14, 1-20. [CrossRef]

11. Budama, L.; Çakir, B.A.; Topel, Ö.; Hoda, N. A New Strategy for Producing Antibacterial Textile Surfaces Using Silver Nanoparticles. Chem. Eng. J. 2013, 228, 489-495. [CrossRef]

12. Ramanujam, K.; Sundrarajan, M. Antibacterial Effects of Biosynthesized MgO Nanoparticles Using Ethanolic Fruit Extract of Emblica Officinalis. J. Photochem. Photobiol. B Biol. 2014, 141, 296-300. [CrossRef] [PubMed]

13. Radetić, M. Functionalization of Textile Materials with TiO2 Nanoparticles. J. Photochem. Photobiol. C Photochem. Rev. 2013, 16, 62-76. [CrossRef]

14. Çakir, B.A.; Budama, L.; Topel, Ö.; Hoda, N. Synthesis of ZnO Nanoparticles Using PS-b-PAA Reverse Micelle Cores for UV Protective, Self-Cleaning and Antibacterial Textile Applications. Colloids Surfaces A Physicochem. Eng. Asp. 2012, 414, 132-139. [CrossRef] 
15. Li, S.; Zhu, T.; Huang, J.; Guo, Q.; Chen, G.; Lai, Y. Durable Antibacterial and UV-Protective Ag/ $\mathrm{TiO}_{2} @$ fabrics for Sustainable Biomedical Application. Int. J. Nanomed. 2017, 12, 2593-2606. [CrossRef]

16. Verbič, A.; Gorjanc, M.; Simončič, B. Zinc Oxide for Functional Textile Coatings: Recent Advances. Coatings 2019, 9, 550. [CrossRef]

17. Lemire, J.A.; Harrison, J.J.; Turner, R.J. Antimicrobial Activity of Metals: Mechanisms, Molecular Targets and Applications. Nat. Rev. Microbiol. 2013, 11, 371-384. [CrossRef] [PubMed]

18. Verbič, A.; Šala, M.; Gorjanc, M. The Influence of in Situ Synthesis Parameters on the Formation of ZnO Nanoparticles and the UPF Value of Cotton Fabric. Tekstilec 2018, 61, 280-288. [CrossRef]

19. Nguyen, H.T.P.; Nguyen, T.M.T.; Hoang, C.N.; Le, T.K.; Lund, T.; Nguyen, H.K.H.; Huynh, T.K.X. Characterization and Photocatalytic Activity of New Photocatalysts Based on Ag, F-Modified ZnO Nanoparticles Prepared by Thermal Shock Method. Arab. J. Chem. 2020, 13, 1837-1847. [CrossRef]

20. Espitia, P.J.P.; Soares, N.d.F.F.; Coimbra, J.S.d.R.; de Andrade, N.J.; Cruz, R.S.; Medeiros, E.A.A. Zinc Oxide Nanoparticles: Synthesis, Antimicrobial Activity and Food Packaging Applications. Food Bioprocess Technol. 2012, 5, 1447-1464. [CrossRef]

21. Moezzi, A.; McDonagh, A.M.; Cortie, M.B. Zinc Oxide Particles: Synthesis, Properties and Applications. Chem. Eng. J. 2012, 185-186, 1-22. [CrossRef]

22. Zhou, G.C.; Sun, L.Z.; Zhong, X.L.; Chen, X.; Wei, L.; Wang, J.B. First-Principle Study on Bonding Mechanism of ZnO by LDA + U Method. Phys. Lett. Sect. A Gen. At. Solid State Phys. 2007, 368, 112-116. [CrossRef]

23. Kolodziejczak-Radzimska, A.; Jesionowski, T. Zinc Oxide-from Synthesis to Application: A Review. Materials 2014, 7, $2833-2881$. [CrossRef] [PubMed]

24. Schmidt-Mende, L.; MacManus-Driscoll, J.L. ZnO—Nanostructures, Defects, and Devices. Mater. Today 2007, 10, 40-48. [CrossRef]

25. Kumaresan, N.; Sinthiya, M.M.A.; Ramamurthi, K.; Ramesh Babu, R.; Sethuraman, K. Visible Light Driven Photocatalytic Activity of $\mathrm{ZnO} / \mathrm{CuO}$ Nanocomposites Coupled with RGO Heterostructures Synthesized by Solid-State Method for RhB Dye Degradation. Arab. J. Chem. 2020, 13, 3910-3928. [CrossRef]

26. Le, T.K.; Nguyen, T.M.T.; Nguyen, H.T.P.; Nguyen, T.K.L.; Lund, T.; Nguyen, H.K.H.; Huynh, T.K.X. Enhanced Photocatalytic Activity of ZnO Nanoparticles by Surface Modification with KF Using Thermal Shock Method. Arab. J. Chem. 2020, 13, 1032-1039. [CrossRef]

27. Barrak, H.; Saied, T.; Chevallier, P.; Laroche, G.; M'nif, A.; Hamzaoui, A.H. Synthesis, Characterization, and Functionalization of ZnO Nanoparticles by N-(Trimethoxysilylpropyl) Ethylenediamine Triacetic Acid (TMSEDTA): Investigation of the Interactions between Phloroglucinol and ZnO@TMSEDTA. Arab. J. Chem. 2019, 12, 4340-4347. [CrossRef]

28. Manikandan, B.; Endo, T.; Kaneko, S.; Murali, K.R.; John, R. Properties of Sol Gel Synthesized ZnO Nanoparticles. J. Mater. Sci. Mater. Electron. 2018, 29, 9474-9485. [CrossRef]

29. Ong, C.B.; Ng, L.Y.; Mohammad, A.W. A Review of ZnO Nanoparticles as Solar Photocatalysts: Synthesis, Mechanisms and Applications. Renew. Sustain. Energy Rev. 2018, 81, 536-551. [CrossRef]

30. Parihar, V.; Raja, M.; Paulose, R. A Brief Review of Structural, Electrical and Electrochemical Properties of Zinc Oxide Nanoparticles. Rev. Adv. Mater. Sci. 2018, 53, 119-130. [CrossRef]

31. Wojnarowicz, J.; Chudoba, T.; Lojkowski, W. A Review of Microwave Synthesis of Zinc Oxide Nanomaterials: Reactants, Process Parameters and Morphologies. Nanomaterials 2020, 10, 1086. [CrossRef]

32. Ali, A.; Phull, A.R.; Zia, M. Elemental Zinc to Zinc Nanoparticles: Is ZnO NPs Crucial for Life? Synthesis, Toxicological, and Environmental Concerns. Nanotechnol. Rev. 2018, 7, 413-441. [CrossRef]

33. Singh, A.; Singh, N.B.; Afzal, S.; Singh, T.; Hussain, I. Zinc Oxide Nanoparticles: A Review of Their Biological Synthesis, Antimicrobial Activity, Uptake, Translocation and Biotransformation in Plants. J. Mater. Sci. 2018, 53, 185-201. [CrossRef]

34. Morkoç, H.; Özgür, Ü. Zinc Oxide: Fundamentals, Materials and Device Technology; John Wiley \& Sons: Hoboken, NJ, USA, 2008; ISBN 3527623957.

35. Gorjanc, M.; Jazbec, K.; Zaplotnik, R.; Vesel, A.; Mozetic, M. Creating Cellulose Fibres with Excellent UV Protective Properties Using Moist CF 4 Plasma and ZnO Nanoparticles. Cellulose 2014, 21, 3007-3021. [CrossRef]

36. Jazbec, K.; Šala, M.; Mozetič, M.; Vesel, A.; Gorjanc, M. Functionalization of Cellulose Fibres with Oxygen Plasma and ZnO Nanoparticles for Achieving UV Protective Properties. J. Nanomater. 2015, 2015. [CrossRef]

37. Primc, G.; Tom, B.; Vesel, A.; Mozeti, M. Biodegradability of Oxygen-Plasma Treated Cellulose Textile Functionalized with ZnO Nanoparticles as Antibacterial Treatment. J. Phys. D Appl. Phys. 2016, 49, 324002. [CrossRef]

38. Hong, G.; Kim, J.; Lee, J.; Shin, K.; Jung, D.; Kim, J. A Flexible Tactile Sensor Using Seedless Hydrothermal Growth of Zno Nanorods on Fabrics. J. Phys. Commun. 2020, 4, 045002. [CrossRef]

39. Baruah, B.; Downer, L.; Agyeman, D. Fabric-Based Composite Materials Containing ZnO-NRs and ZnO-NRs-AuNPs and Their Application in Photocatalysis. Mater. Chem. Phys. 2019, 231, 252-259. [CrossRef]

40. Nurelissa, I.; Ramzuz, M.; Zakaria, N.; Zain, Z.M. Synthesis and Characterization of Zinc Oxide Nanostructures in Biosensor Application. Int. J. Biosens. Bioelectron. 2020, 6, 48-54. [CrossRef]

41. Sabir, S.; Arshad, M.; Chaudhari, S.K. Zinc Oxide Nanoparticles for Revolutionizing Agriculture: Synthesis and Applications. Sci. World J. 2014, 2014, 925494. [CrossRef] [PubMed]

42. Shaheen, T.I.; El-Naggar, M.E.; Abdelgawad, A.M.; Hebeish, A. Durable Antibacterial and UV Protections of in Situ Synthesized Zinc Oxide Nanoparticles onto Cotton Fabrics. Int. J. Biol. Macromol. 2016, 83, 426-432. [CrossRef] 
43. El-Naggar, M.E.; Shaarawy, S.; Hebeish, A.A. Multifunctional Properties of Cotton Fabrics Coated with in Situ Synthesis of Zinc Oxide Nanoparticles Capped with Date Seed Extract. Carbohydr. Polym. 2018, 181, 307-316. [CrossRef]

44. Zhang, G.; Morikawa, H.; Chen, Y.; Miura, M. In-Situ Synthesis of ZnO Nanoparticles on Bamboo Pulp Fabric. Mater. Lett. 2013, 97, 184-186. [CrossRef]

45. Ali, A.; Baheti, V.; Vik, M.; Militky, J. Copper Electroless Plating of Cotton Fabrics after Surface Activation with Deposition of Silver and Copper Nanoparticles. J. Phys. Chem. Solids 2020, 137, 109181. [CrossRef]

46. Scherrer, P. Göttinger Nachrichten Math. Phys 1918, 2, 98-100.

47. Mansoor, T.; Hes, L.; Skenderi, Z.; Siddique, H.F.; Hussain, S.; Javed, A. Effect of Preheat Setting Process on Heat, Mass and Air Transfer in Plain Socks. J. Text. Inst. 2019, 110, 159-170. [CrossRef]

48. Ran, J.; He, M.; Li, W.; Cheng, D.; Wang, X. Growing ZnO Nanoparticles on Polydopamine-Templated Cotton Fabrics for Durable Antimicrobial Activity and UV Protection. Polymers 2018, 10, 495. [CrossRef]

49. Jiao, L.; Ma, J.; Dai, H. Preparation and Characterization of Self-Reinforced Antibacterial and Oil-Resistant Paper Using a NaOH/Urea/ZnO Solution. PLoS ONE 2015, 10, e0140603. [CrossRef]

50. Sun, X.Z.; Bremner, D.H.; Wan, N.; Wang, X. Development of Antibacterial ZnO-Loaded Cotton Fabric Based on in Situ Fabrication. Appl. Phys. A Mater. Sci. Process. 2016, 122, 940. [CrossRef]

51. Becker, J.; Raghupathi, K.R.; Pierre, J.S.; Zhao, D.; Koodali, R.T. Tuning of the Crystallite and Particle Sizes of ZnO Nanocrystalline Materials in Solvothermal Synthesis and Their Photocatalytic Activity for Dye Degradation. J. Phys. Chem. C 2011, 115, 13844-13850. [CrossRef]

52. Trenque, I.; Mornet, S.; Duguet, E.; Gaudon, M. New Insights into Crystallite Size and Cell Parameters Correlation for ZnO Nanoparticles Obtained from Polyol-Mediated Synthesis. Inorg. Chem. 2013, 52, 12811-12817. [CrossRef] [PubMed]

53. Khorsand Zak, A.; Razali, R.; Abd Majid, W.H.; Darroudi, M. Synthesis and Characterization of a Narrow Size Distribution of Zinc Oxide Nanoparticles. Int. J. Nanomed. 2011, 6, 1399-1403. [CrossRef] [PubMed]

54. Sivakumar, P.M.; Balaji, S.; Prabhawathi, V.; Neelakandan, R.; Manoharan, P.T.; Doble, M. Effective Antibacterial Adhesive Coating on Cotton Fabric Using ZnO Nanorods and Chalcone. Carbohydr. Polym. 2010, 79, 717-723. [CrossRef]

55. Chung, C.; Lee, M.; Choe, E.K. Characterization of Cotton Fabric Scouring by FT-IR ATR Spectroscopy. Carbohydr. Polym. 2004, 58, 417-420. [CrossRef]

56. Javed, A.; Azeem, M.; Wiener, J.; Thukkaram, M.; Saskova, J.; Mansoor, T. Ultrasonically Assisted In Situ Deposition of ZnO Nano Particles on Cotton Fabrics for Multifunctional Textiles. Fibers Polym. 2021. [CrossRef]

57. Shao, D.; Gao, Y.; Cao, K.; Wei, Q. Rapid Surface Functionalization of Cotton Fabrics by Modified Hydrothermal Synthesis of ZnO. J. Text. Inst. 2017, 108, 1391-1397. [CrossRef]

58. Wu, D.; Long, M.; Zhou, J.; Cai, W.; Zhu, X.; Chen, C.; Wu, Y. Synthesis and Characterization of Self-Cleaning Cotton Fabrics Modified by TiO2 through a Facile Approach. Surf. Coatings Technol. 2009, 203, 3728-3733. [CrossRef]

59. Javed, A.; Azeem, M.; Saskova, J. P024_0663_ UV Protective Fabrics by Application of Ball Milled Neem Tree Leaves. In Proceedings of the 19th World Textile Conference-Autex 2019, Ghent, Belgium, 11-15 June 2019; p. 3.

60. Matsumura, Y.; Ananthaswamy, H.N. Toxic Effects of Ultraviolet Radiation on the Skin. Toxicol. Appl. Pharmacol. 2004, 195, 298-308. [CrossRef]

61. Young, A.R. Acute Effects of UVR on Human Eyes and Skin. Prog. Biophys. Mol. Biol. 2006, 92, 80-85. [CrossRef]

62. Narayanan, D.L.; Saladi, R.N.; Fox, J.L. Ultraviolet Radiation and Skin Cancer. Int. J. Dermatol. 2010, 49, 978-986. [CrossRef]

63. Piacentini, R.D. The Importance of the Use of Clothes with Solar UV Protection. Curr. Trends Fash. Technol. Text. Eng. 2018, 3, 96-100. [CrossRef]

64. Gies, P.; Slevin, T.; Harrison, S.; Plowman, P.; Dain, S.; Moller, L.; Mawley, F.; Swift, N. Australian/New Zealand Standard, AS/NZS 4399: 2017: Sun Protective Clothing-Evaluation and Classification; Standards Australia: Sydney, Australia, 2017 ; ISBN 1760358843.

65. Alebeid, O.K.; Zhao, T. Review on: Developing UV Protection for Cotton Fabric. J. Text. Inst. 2017, 108, 2027-2039. [CrossRef]

66. Khan, M.Z.; Militky, J.; Baheti, V.; Fijalkowski, M.; Wiener, J.; Voleský, L.; Adach, K. Growth of ZnO Nanorods on Cotton Fabrics via Microwave Hydrothermal Method: Effect of Size and Shape of Nanorods on Superhydrophobic and UV-Blocking Properties. Cellulose 2020, 27, 10519-10539. [CrossRef]

67. Anita, S.; Ramachandran, T.; Rajendran, R.; Koushik, C.V.; Mahalakshmi, M. Preparation and Characterization of Zinc Oxide Nanoparticles and a Study of the Anti-Microbial Property of Cotton Fabric Treated with the Particles. J. Text. Appar. Technol. Manag. 2010, 6. Available online: https:/ / ojs.cnr.ncsu.edu/index.php/JTATM/article/view/899/723 (accessed on 15 July 2021).

68. Souza, D.A.R.; Gusatti, M.; Ternus, R.Z.; Fiori, M.A.; Riella, H.G. In Situ Growth of ZnO Nanostructures on Cotton Fabric by Solochemical Process for Antibacterial Purposes. J. Nanomater. 2018, 2018. [CrossRef]

69. El-Nahhal, I.M.; Salem, J.; Anbar, R.; Kodeh, F.S.; Elmanama, A. Preparation and Antimicrobial Activity of ZnO-NPs Coated Cotton/Starch and Their Functionalized ZnO-Ag/Cotton and Zn(II) Curcumin/Cotton Materials. Sci. Rep. 2020, $10,5410$. [CrossRef]

70. Joe, A.; Park, S.H.; Shim, K.D.; Kim, D.J.; Jhee, K.H.; Lee, H.W.; Heo, C.H.; Kim, H.M.; Jang, E.S. Antibacterial Mechanism of ZnO Nanoparticles under Dark Conditions. J. Ind. Eng. Chem. 2017, 45, 430-439. [CrossRef]

71. Hatamie, A.; Khan, A.; Golabi, M.; Turner, A.P.F.; Beni, V.; Mak, W.C.; Sadollahkhani, A.; Alnoor, H.; Zargar, B.; Bano, S.; et al. Zinc Oxide Nanostructure-Modified Textile and Its Application to Biosensing, Photocatalysis, and as Antibacterial Material. Langmuir 2015, 31, 10913-10921. [CrossRef] [PubMed] 
72. Sudrajat, H. Superior Photocatalytic Activity of Polyester Fabrics Coated with Zinc Oxide from Waste Hot Dipping Zinc. J. Clean. Prod. 2018, 172, 1722-1729. [CrossRef]

73. Shaban, M.; Abdallah, S.; Khalek, A.A. Characterization and Photocatalytic Properties of Cotton Fibers Modified with ZnO Nanoparticles Using Sol-Gel Spin Coating Technique. Beni-Suef Univ. J. Basic Appl. Sci. 2016, 5, 277-283. [CrossRef] 